\title{
Political Leadership and Democratic Governance from the Perspective of Slovak Youth
}

\author{
Jaroslav Mihálik ${ }^{1}$
}

Katedra politlógie a európskych štúdií, Fakulta sociálnych vied UCM, Trnava

\begin{abstract}
Political Leadership and Democratic Governance from the Perspective of Slovak Youth The aim of this paper is to explore the modern trends of political leadership in relation to young generation in Slovakia as interpreted by the results from international collaborative research project. The author tries to address the issues of trust, attitudes and challenges within democratic governance and political leadership in contemporary political and social agenda in the specific case study of Slovakia. First, we use the theoretical approaches to understand political leadership in context and then we apply the qualitative analysis of individual interviews with respondents in two field sites in Slovakia to link the issues of democratic governance and political leadership. Finally, using the survey data and quantitative statistical analysis we measure the political trust and attitudes of young people toward politicians and social organizations. This paper confirms the relatively large negative positions of young people to their political interest, trust, attitudes to political elites and practical democratic performance.
\end{abstract}

Key words: political leadership, youth, political trust, MYPLACE, democracy, governance

\section{Acknowledgement}

This study was prepared under the post-doctoral fellowship program at Charles University in Prague, project title: Political Leadership and Conflict Resolution in Contemporary World.

Politické líderstvo a demokratické vládnutie očami slovenskej mládeže $V$ štúdii skúmame moderné trendy politického vodcovstva vo vzt’ahu k mládeži na Slovensku na základe výsledkov medzinárodného výskumného projektu. Autor interpretuje dimenzie dôvery, postojov a výziev demokratického vládnutia a politického vodcovstva v súčasnej politickej a sociálnej agende $v$ rámci prípadovej štúdie Slovenskej republiky. Použitím teoretických východísk politického vodcovstva aplikujeme kvalitatívnu analýzu rozhovorov s respondentmi v dvoch výskumných lokalitách na Slovensku, ktoré interpretujú vzt'ah medzi demokratickým vládnutím a politickým vodcovstvom. Následne využívame kvantitatívnu štatistickú analýzu pre meranie dôvery a postojov mladých ludí voči politickým elitám a inštitúciám. $Z$ hl'adiska svojich ciel'ov štúdia potvrdzuje relatívne rozsiahle negatívne postoje mladých ludí k záujmu o politiku, dôveru a názory voči politickým elitám a kritiku demokracie.

Klúčové slová: politické vodcovstvo, mládež, politická dôvera, MYPLACE, demokracia, vládnutie

\section{Grantová informácia}

Táto štúdia bola realizovaná $v$ rámci post-doktorandského výskumného grantu Univerzity Karlovej v Prahe pod názvom: Politické vodcovstvo a riešenie problémov v súčasnom svete.

1 PhDr. Jaroslav Mihálik, PhD., assistant professor and researcher, Faculty of Social Sciences, University of Ss. Cyril and Methodius, Trnava, Slovakia, email: jaroslav. mihalik@ucm.sk. His research covers youth political and civic engagement, nationalism studies and trends of political leadership and democratic performance. 


\section{Research context}

In addressing the international research project MYPLACE (Memory, Youth, Political Legacy and Civic Engagement) we assume that current political trends and democratic consolidation in essence represent goals and broader interest of scientific research in relation to the younger generation. Current trends of political developments reflect the fight against totalitarian, authoritarian populist and fascist regimes which in regard of shared collective memory divided as well unified the European continent. It is therefore necessary to academically contribute to this trend in order to professionally examine and interpret current political and civic motivation of young people as well as to evaluate their relationship to the collective memory and political heritage. Dominantly, young Europeans shall be the carriers of modern political thoughts and should critically address the negative social and historical circumstances and events, mostly those that occurred during 20th century.

These processes are inevitably linked to political and civic participation of young people, the spread of liberal thoughts and ideas and creation of non-discrimination and society wide tolerance. Youth organizations, youth movements or any other and various formal and informal youth associations provide for development of the wisdom and knowledge about the recent historical grievance, awareness and past mistakes. Therefore, it is also their duty to inform and eliminate potential dangers that young people face in today's globalized world.

The target group of the MYPLACE project is current young generation up to 30 years of age. This generation is bound mainly with the experience that they have grown up in the European area with the absence of left-wing or right-wing authoritative regime. Similar to this, there is a lack of practically any primary experience with the previous regime, prejudice and fear of the Cold War and, essentially with no exceptions with life under communism, socialism and fascism or any other authoritarian political regime at all. On the other hand, we admin that current generation of young people is the group which intensively lives the age of global capitalist crisis since the World War II. Moreover, in comparison to previous generations of young people current youth does not surrender the requirements of authoritarian regime, but instead the uniformity and adaptation have been substituted by the prism of individualism and increased pressure to secure their own benefit (Furlong-Cartmel, 1997).

Like the current integrated Europe deals with the economic and political recession, as well as social and economic position of young people, especially in the labor market, causes considerable problems. From these reasons, the authors (Ignazi, 2003) identify the inclination of the ,vulnerable" new generation to populist, radical and extremist groups, political parties and their leaders and movements which benefit from the rhetoric of euroscepticism, anti-globalization and anti-capitalism. 
It is to be noted that support for these entities is attractive precisely among the youth of those countries and the European regions where the evident frustration and disappointment of unfulfilled promises had been proclaimed during the system transformation and transition to democracy. In this respect, it is possible to identify the alternative leaders and representatives of such entities using voter and civic potential of youth to their usurpation of power and political influence. But there is no empirical evidence that young people are being clearly manipulated by extremist groups, or alternative movements, which use the young people as an instrument of their own legitimacy. In principle, we can conclude that the public interest in the political process is driven mainly through the results of political and civic participation, which confirmed that the primary interest of young people is not vested in the knowledge of the domestic political scene, individual institutions and their representatives, but rather through alternative modes of governance and conspiracy theories. Similarly, informal ways of learning and the acquisition of information about politics and history outweigh the traditional forms of education system and teaching process in the school system.

Various political heritage and collective memory of the nation is a key argument of research in relation to youth. From this perspective, we can interpret the history, memory and political message as kind of mind set of policies that should represent the starting point for understanding their past ancestors and ideologies for the current generation of young people. Nation in this sense represents the political state of mind, from genealogical principle of theories of nationalism and the perception of the nation and national identity. Research of the historical memory of youth and political heritage is thus a necessary component of establishing a common understanding and consensus within transnational social interaction.

This research study aims to outline and analyze the context, methods and empirical data together with the key findings and features of 60 semi-structured interviews in two field site locations in Slovakia. The study is structured to measure and compare the political participation, political knowledge, history and political transmission, as well as concerns about social problems, among a sample of 60 interviewees in two distinctive locations selected under the criteria outlined in the next chapter. We also use the figures from quantitative sociological survey within the same research project tested on 1200 respondents ( $n=600$ in Trnava and n=600 in Rimavská Sobota).

Since there is no definite and unique legislation in Slovakia to categorize and operate youth as a social and age group, from the international scope of the research project we standardized the age range from 15 to 25 years. Although, our sample consisted several respondents aged 26 we have not excluded them from the research and analysis. The youth then represents a specific socio-demographic group from the sociological perspective and, at the same time a specific life period from the psychological point of view. 
Table 1: Socio-demographic profile of the interviewees $(n=60)$

\begin{tabular}{|c|c|c|c|}
\hline & & Trnava & Rimavská Sobota \\
\hline \multirow[t]{2}{*}{ Gender } & male & 19 & 15 \\
\hline & female & 11 & 15 \\
\hline \multirow{3}{*}{ Age } & $\begin{array}{l}\text { group } 1 \\
(15-18)\end{array}$ & 5 & 13 \\
\hline & $\begin{array}{l}\text { group } 2 \\
(19-22)\end{array}$ & 15 & 11 \\
\hline & $\begin{array}{l}\text { group } 3 \\
(23-26)\end{array}$ & 10 & 6 \\
\hline \multirow{4}{*}{ Nationality } & Slovak & 29 & 20 \\
\hline & Roma & 0 & 1 \\
\hline & Hungarian & 0 & 5 \\
\hline & Mixed & 1 & 4 \\
\hline \multirow{4}{*}{ Employment status } & In full-time education & 15 & 17 \\
\hline & In full-time employment & 6 & 5 \\
\hline & In part-time employment & 5 & 2 \\
\hline & Unemployed & 4 & 6 \\
\hline \multirow[t]{8}{*}{ Education } & $\begin{array}{l}\text { Currently in general academic secondary } \\
\text { education }\end{array}$ & 2 & 4 \\
\hline & $\begin{array}{l}\text { Currently in vocational secondary } \\
\text { education }\end{array}$ & 6 & 8 \\
\hline & $\begin{array}{l}\text { Completed general academic secondary } \\
\text { education }\end{array}$ & 2 & 0 \\
\hline & $\begin{array}{l}\text { Completed vocational academic secondary } \\
\text { education }\end{array}$ & 5 & 8 \\
\hline & Currently at university & 13 & 6 \\
\hline & Completed university & 2 & 2 \\
\hline & $\begin{array}{l}\text { Currently in post-secondary vocational } \\
\text { training }\end{array}$ & 0 & 1 \\
\hline & Other & 0 & 1 \\
\hline \multirow{2}{*}{ Family status } & Single & 30 & 28 \\
\hline & Married or living with partner & 0 & 2 \\
\hline \multirow{5}{*}{ Residential status } & Live at home with parent(s) & 21 & 28 \\
\hline & $\begin{array}{l}\text { Live at home with other relatives e.g. } \\
\text { grandparents }\end{array}$ & 1 & 1 \\
\hline & Live independently alone & 5 & 1 \\
\hline & $\begin{array}{l}\text { Live independently with own partner/ } \\
\text { children }\end{array}$ & 1 & 0 \\
\hline & Live independently with friends & 2 & 0 \\
\hline
\end{tabular}




\section{Understanding Political Leadership}

Leadership shall be understood as a key feature of any governmental structure, from small organizations to nation states and supranational levels. All means of governance require good and just leaders, structures and administration. On a contrary, if the political leadership lacks some substantial and progressive adjustments we can talk about weak leadership that usually leads to government failures and unavailability to respond to modern demands and globalization issues. Authors specifically argue (Brysk 2002, Masciulli-Day 2006) that in globalized networks the political agenda needs to be prepared for new forms of international and supranational leadership, such as transnational flows of people, production, investment, information, ideas and authorities. Moreover, the leaders need to embrace new ideas, visions, solutions and methods in order to adapt and gain political powers.

To study the concepts of political leadership we need to take into account its historically grounded models, which, usually have been changed over time and historical periods. In order to be able to adequately respond to the new social and political changes and to affect such processes the political leaders are required to be prepared to change the routinized schedules and to abandon the old policies that do not narrowly correspond with the changes. As advocated by the authors (i.e. King 2002, Greenstein 2004) political leadership is researched as a multidimensional aspect of political life. According to them, leadership is a part of multicausal social process that brings about particular political outcomes such as electoral results or integration process. Political leaders are then dependent on the supporters of their policy agenda and they seek to guarantee their positions. The political leadership is thus always challenging and demanding concept. It is therefore important to study and analyze the approaches of political leadership to conflict resolution from different positions as well as in particular environments (local, regional, national and supranational). In this respect, we focus on interpretation from two local field sites in Slovakia and we do not aim to generalize the context of the interviews and survey data, although it is possible to compare with the national level.

The principle and context of leadership is one of the oldest and most examined features of humanity and organization matters. It is also well contested and explored area throughout the historical development and human nature. As advocated in the variety of literature the topics on leadership have been matter of interest over the hundreds of years from the ancient philosophers such as Plato and Socrates through the republican governments and rulers to the rise of modern democracies and, especially the nation building process (Bolden, 2004; Choi, 2007; Masciulli-MolchanovKnight, 2009). One of the greatest challenges of modern political leadership both in interpretation and practice was present during the 20th century and the events related 
to it, such as totalitarian regimes and dictatorship, difficult pasts and challenges to European integration.

While the previous century was highly affected by the challenges of totalitarian systems and the struggle for independence and democracy, the last two decades of the 20th century were marked by the system transformation and the newly emerged (reestablished) states sought for prompt and smooth international integration. However, the post integration process is then marked with the globalization issues, sovereignty loss, criticism towards the EU and the solution of regional or local problems. Moreover, new economic and social struggles emerged which create crisis scenarios and the rise of populism as well as nationalism in the nation states. We witness the new wave of modern nationalism and radicalization of strong political parties and leaders (such as Fidesz in Hungary and SMER-SD in Slovakia) since they have substituted the nationalists who failed to address the national and populist policy to the voters (Horváth, Mihálik 2011). Similarly, there are social and political issues related to the minority civic and political integration in the countries of Central Eastern Europe. Political leaders seek to use the popular concepts and nationalist rhetoric to attract as many voters as possible. The factual differences among political subjects diminish and the political agenda is based to catch the voter instead of providing a clear political program. We observe the continuous support for extremist groups and parties which offer solutions to the unpopular ethnic issues. This is the open arena for political alternatives and alteration of the leadership. We argue that populism, radicalism and nationalism present at current political elites are the main sources of voters' and public support. Nationalism and populism may be considered as the relevant and inclusive aspects of the electoral struggle and campaigning. From this reason, it is necessary to link the dimensions of political leadership in its theoretical perspective, comparative narratives and problem-driven issues that are present in particular societies and political agenda, especially in relation to younger generation.

Although there is a robust academic debate and discourse over the typologies of political leadership in order to pose and answer questions about leaders, followers, objectives, situations and contexts (Masciulli, Molchanov, Knight 2009) there is lack of comprehensive and comparative data to connect the modern political leadership in a globalized world to various approaches of conflict resolution. One might argue that there is not enough political area for new states and their political elites (Visegrad countries, Balkan region, Baltic States) to support and envisage the common political grounds such as the position of the EU and NATO to emerged conflicts and problems (the economic and social crisis, rise of nationalism and extremism, inter-state conflicts). On the other hand, we witness the different positions and approaches of national elites in the context of conflict resolution (such as the case study of Visegrad countries and Baltic States and their different approaches to Russia-Ukraine conflict). 
All of these issues are inevitably bound with the political leadership on the national as well as international level. The scope of the study reflects such problems and gives arguments to the raised questions. The research deals with the current political development and issues of political leadership in multi-regional dimension but, thanks to its wider perspective it goes beyond the territorial borders.

Based on the normative and empirical typologies of political leadership, i.e. Nye's modern normative typology (2008) and/or Weber's typology (1986) we seek to demonstrate different patterns and approaches of modern political leadership in globalized perspective, such as EU integration and post-integration period. We argue that concerns and issues of political leadership in the 21 st century are dominantly influenced by national, regional and local problems rather than global conflicts. The legitimacy and political agenda of national elites is driven exclusively from the demands and expectations on local and national level only.

There has been a complete set of research questions to address the problem:

- What is the general position and understanding of democratic governance of young people in selected field sites?

- Is there a political leader or political platform that is favored by young generation?

- How do young people recognize and evaluate the existence of various political and social institutions?

- Is there any particularly relevant trust to these institutions?

- What is the understanding of political leadership among young respondents?

We may structure the research design as combination of multi causal process using the quantitative and qualitative research and subsequent data analysis as illustrated in the table below:

Table 2: Research design of political leadership and conflict resolution

\begin{tabular}{|l|l|l|}
\hline Political leadership & Factors of leadership & $\begin{array}{l}\text { Conflict resolution and } \\
\text { expectation }\end{array}$ \\
\hline Quantitative research & Qualitative research & $\begin{array}{l}\text { Synthesis and } \\
\text { interpretation }\end{array}$ \\
\hline $\begin{array}{l}\text { Trust to political leaders, } \\
\text { political parties and } \\
\text { other social institutions }\end{array}$ & $\begin{array}{l}\text { Attitudes to politics, } \\
\text { political actors and leaders }\end{array}$ & $\begin{array}{l}\text { Typology of political } \\
\text { leadership }\end{array}$ \\
\hline $\begin{array}{l}\text { Democratic governance } \\
\text { and performance }\end{array}$ & $\begin{array}{l}\text { Understanding democracy } \\
\text { in everyday life } \\
\text { Civic and political rights }\end{array}$ & $\begin{array}{l}\text { New trends and } \\
\text { challenges of political } \\
\text { leadership }\end{array}$ \\
\hline
\end{tabular}




\section{Young People's Attitude to Democratic Governance}

The general attitude of young generation toward democratic governance and related interest in politics depends specifically on the level of knowledge about history, politics, facts and events. Then the family environment and education system are factors of youth influence and political socialization. Derived from this, the general interest in politics is understood as one of the traditional indicators of the political and civic engagement of young people and also reflects trends in political leadership and its understanding. This has also impact on political and civic socialization of young people in global and their potential to engage in particular forms of democratic governance (Macháček, 2008).

As argued, the important values shaping civic life are largely shared within the community in a relative broader pursuit of social cohesion which also belongs to the factors of democratic society development. On a contrary, this statement does not imply that there is no consensus on problem and conflict resolution but the agreement is reached without any particular self-destructive political struggle.

The figure below illustrates the general satisfaction with democratic procedures and democracy itself among young people as reported in there survey $(n=1200)$ in two research locations in Slovakia (MYPLACE research):

Figure 1: General evaluation of democratic governance across two field sites ("How satisfied are you with the way democracy works in Slovakia?")

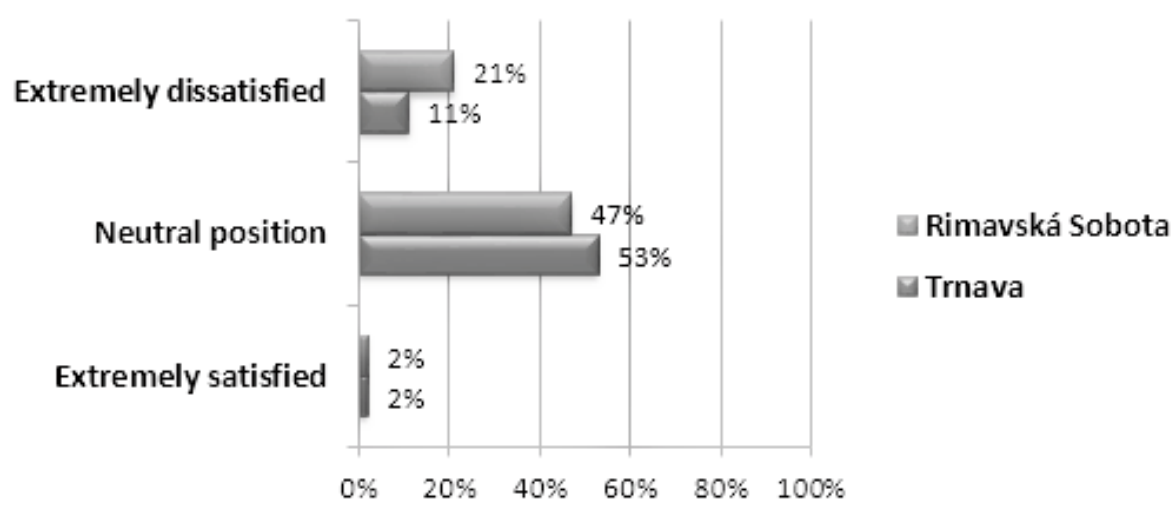

From the comparative overview the presented results indicate that in the region of Rimavská Sobota there are slightly more young people who are not satisfied with democracy at all while in the other location there are young people with preferences over the median values - the discrepancy in the neutral position is rather invisible across the two research locations. 
The survey analysis indicates that in both locations, the youngest cluster of respondents of 16-17 years is extremely satisfied with democracy (altogether approximately $2 \%$ in each location). In Rimavská Sobota, there is a rare agreement concerning satisfaction with democracy between the ethnic majority (Slovak) and minority (Hungarian).

From the qualitative analysis of the individual interviews we may suggest that democracy is understood positively in 49 cases out of 60 . From the practical overview of democratic performance in Slovakia 34 interviewees claimed that Slovakia is currently democratic or more democratic that in the past or during different political regimes. In contrast to this, 22 interviewees consider democracy as a negative part of our lives and also stated that democracy is not a good system of governance. Additionally, three respondents claimed that currently there is lack of democracy or no democracy at all. The typical argumentation of the interviewees referred to the existence of something that can be systematically labelled as democracy but not in its full complete merits since "democracy exists but it could also be better" (Daniel, Rimavská Sobota).

The collection of positive understanding of democracy is literally driven by rather abstract references to freedoms and rights as illustrated below:

It is an advantage, a person has their own mind and can express themselves. (Evka, Rimavská Sobota)

A democracy? Some kind of freedom. (Fodor, Rimavská Sobota)

Freedom of speech, freedom of movement, then free market, etc... (Bocian, Trnava)

Democracy is the rule of majority, of the people, free to choose their representatives. Freedom and options. (Dajo, Trnava)

More specifically, interviewees express enjoyment of having more freedom than before or compared to their predecessors: "yes, we can talk about what we want and we are free to travel, so it is good" (Evka, Rimavská Sobota). They also consider democracy as one of the tools or means to shape individual futures: "we can go and vote, we can shape the future, this is democratic to me" (Daniel, Rimavská Sobota).

In general, we recorded more positive references suggesting that Slovakia is a standard democratic party compared to those claiming there is no democracy at all. The interviewed young people have practically no experience with the previous regimes, undemocratic procedures and they should be considered as a concept of tabula rasa although there were some references to situation in which they felt they are not able to speak freely or to express their visions and attitudes. These usually refer to such 
experiences within the education system or during the early career development, i.e. at work.

When integrating the comments and references to democracy in Slovakia, we incorporated both general reflections toward democracy with some caveat about its practical performance: "although there is a sort of democracy we have a long way to go to make it better" (Leila, Rimavská Sobota). From this reason we elicit that some respondents accept the line about a system of democratic governance in Slovakia but suggest there are some limits to overcome and we still need some improvements to be implemented, especially in the field of judicial system, education and health care. In general, they are positive regarding the democratic standards and values such as freedoms of speech and movement or freedom to choose especially when we compare with the status quo of the previous regime when their parents were not allowed to enjoy such freedoms as identified by interviewees. A respondent suggested that Slovakia may be more democratic than before because the older generation is slowly disappearing. We assume that young people nowadays view the older generations as a physical embodiment of the previous periods, namely the communist Czechoslovakia while the younger generation is limitless and free of personal relation and connection to communism. On the other hand, the new generation creates the new social discourse in civic and political life as well as it reproduces the attitudes and arguments of the older generation.

Following this line of thought, the younger generation is more open to democracy even though it may be aware of its imperfect state of art. Interview narratives thus tend towards the view of democratic governance and life in Slovakia that suggests people in Slovakia live in a democratic society, which is governed by the rule of law, while the creation of something that mirrors western type democracy is still a work in progress.

Comparing references to democracy then and now, since the vast majority of respondents were born after 1989, their knowledge is derived mainly from parents and grandparents, including the school environment and friends as well as media. Usually, the interviewees argue that the lack of democracy previously was offset by the social guarantees and equality people enjoyed. They also described the previous system as ordered and not characterized by the chaos caused by democratic instability. The system today, respondents suggest, is quite democratic and people do what they want compared to the pre-1989 period. It is interesting, that people consider the system in Slovakia as democratic even when they refer to the system as one of partocracy or limited democracy. When they comment that there is no democracy in Slovakia respondents also added caveats such as "I don't know why there is no democracy I should probably remind myself what democracy is" (Dusan, Trnava) or suggested that, while people are equal in general, some are "more equal than others" (Tomas, Trnava). For some, democracy is a scam that has brought capitalism, crime and a worse 
social and economic situation for individuals. For others it is simply meaningless: "democracy means nothing to me" (Belo, Rimavská Sobota). We illustrate some of the contextual narratives:

Today's democracy? I think it is one big [beep]. It is a scam. It is just a police state. Nothing more, just a scam. This is no democracy. Absolutely not. I think this is not democracy, because if it was, everyone would have a chance to express themselves and vote and so on. But everything is driven by the power of money - the power of money and fear. People are afraid that they will lose what they have. (Cziko, Rimavská Sobota)

As interpreted in variety of statements and its analysis on democracy it is clear that despite significant usage of democracy and democratic many of the respondents are still unsure about the meaning of it in everyday life. Some of the interviewees tend to stress the limits of democracy or the lack of democracy for example in the financial sphere. On the other hand, some express concerns that democracy may be too vague and unknown or too abstract for ordinary people who do not think about it every day, which may result in chaos, anyway. The respondents agree that governance by the people would end in a great chaos (Veronika, Trnava).

Those interviewees who express positive feelings about democracy define it mostly as the reference to the freedoms that should be guaranteed through the rule of law and civic rights. They also recognize the meaning of democracy may be substituted based on experience or time lapses: "for me, democracy is what we have now. I cannot see or judge the regime from previous times since I have never experienced it. But definitely, democracy mean different things to people who, for example, rescued or escaped during 1968 than what it means to me, however" (Bohdan, Trnava).

In the majority of statements, the concept of a better society is a fair society which includes such democratic values as: equality, compromise, no conflicts, fair-play, employment, no prejudice, rule of law. A better society is when "everyone accepts the rules of the game and acts fairly" (Dajo, Trnava) or "there should be equality and employment for everyone" (Sona, Rimavská Sobota).

The respondents are in favor of a better and fair society: "I think fair society is better, the society would be much better if it was fair" (Lucy, Rimavská Sobota). The better society should be fair to everyone. According to respondents a better society is when people are honest, without envy, respect each other, and have equal rights. For example, "people should have right to employment and education, tolerate each other and be equal" (Sona, Rimavská Sobota). Generally, a sense of tolerance is evident when suggesting the context of a better society. For some a better society would bring, above all, more job opportunities. From a negative position, however, a better society can also be one that excludes others or limits diversity: "I think without Roma it would be better" (Tomas, Rimavská Sobota); or "we should live as a single nation without lots of political 
parties" (Ibid). According to some interviewees, the concept of a fair and good society is considered as utopia since it is not possible to achieve it. They consider it desirable but almost 100 per cent infeasible or beyond imagination and application.

Ultimately, respondentsare also skeptical and critical toward democratic governance, they synonymize it with partocracy, autocracy and limited democracy. One respondent is not quite sure what to expect from democracy, since he should probably remind what the democracy actually means. The others stress inequality, capitalism as a negative part of society and worsened social and economic situation for individuals from the prospect of system transformation.

\section{Political Trust and Attitudes to Political Leadership Among Slovak Youth}

Regarding the political opinions and attitudes of young people, we identified an area (corruption of politicians, inappropriate influence of the rich onto politics, low interest of politicians in youth) of critical and negative assessment of politics and politicians that did not depend on the level of political knowledge of respondents.

The empirical hypothesis of the relation between the level of civic knowledge and inclination or resistance of young citizens to authoritarianism was already tested in several survey sets. Results of EUYOUPART (2005) confirmed that the knowledge of democratic principles enables young people understand how democracy works and refuse, more often, authoritative personality in the political life.

Results of the MYPLACE survey in Trnava confirmed that the group of proponents of a stronger position of a leader predominantly consisted of respondents with the lowest level of civic knowledge (strongly agree as many as 22.5\%) and the lowest number of respondents with the highest level of civic knowledge (strongly agree only 8.3\%). In the rural district of Rimavská Sobota, the overall structure of inclination or rejection of authoritative personality is influenced by the fact that a large share of respondents, even those with the highest level of political knowledge, do not mind if the political personality that is in the lead does or does not depend on the parliament (as many as $45 \%$ ). The traditional urban-rural conflict was evidenced in the case of resistance to an authoritative personality and strengthening of the position of the parliament. In Trnava, it was $44.8 \%$ of respondents but in the rural area of Rimavská Sobota only $34.2 \%$.

The above implies that the people in the city of Trnava have clearer attitudes to the political topic. There are young citizens there who support authoritarianism less and rather oppose it. That is fully in line with sociological analyses that, in the long run, have claimed that the urban-rural division line in Slovakia is important. Based on the findings, citizens living in rural areas are more conservative, more nationalistic, and more religious. Verification of the hypothesis that citizens in rural areas are much 
more inclined to authoritarianism than people living in towns rather means that a significant group of young rural citizens (Rimavská Sobota), even those with high level of knowledge of politics, do not either support or resists the orientation and they do not find it either good or bad.

Based on empirical findings of the MYPLACE survey we verified the hypothesis that a low level of political knowledge is strongly connected to the highest support to authoritarian procedures in governance. Even though the group of young people in Trnava with the lowest level of political knowledge is the smallest out of all (15.3\%), it showed the strongest support to a strong personality of a leader (22.3\%). That is in line with knowledge of mobilization of a part of the youth in the city of Trnava in favour of radical action groupings of sport fan clubs.

Our research showed that the attitude of young people to politics and politicians is very critically defined. Prevailing negative evaluations at the level of $66-70 \%$ could be found in all three issues. The most significant is the evaluation that politicians are corrupt, followed by the view that the rich have too much influence on politics, and that the claim they are interested in the young generation is false.

We have confirmed that the individual evaluations are statistically different in the studied locations. As for Trnava location, the evaluations are more negative. From the structural point of view, negative evaluations with diverse variations can be found. Sometimes it is a matter of the unemployed, sometimes of the employed, graduates or people without A-level.

Negative evaluations of interest of politicians in youth can be found mainly among the unemployed (Rimavská Sobota - 28\% compared to Trnava - 41.3\%). In Rimavská Sobota, the unemployed claimed that politicians are corrupt (33.9\%), but in Trnava it is claimed mostly by the employed (41.7\%)

In Rimavská Sobota, mainly the group of employed young people think that the rich have too much influence on politics (36.4\%), but in Trnava this number is even higher reaching $41.5 \%$. In location of Trnava it is believed by the university students (44\%) and the members of the highest class (45.8\%), but in Rimavská Sobota it is believed mainly by the respondents with no A-level (46.7\%) and the middle class members (46.7\%). 
Figure 2: Attitudes towards politicians across field sites ("How much do you agree/disagree with the following statements?')

\section{Trnava}

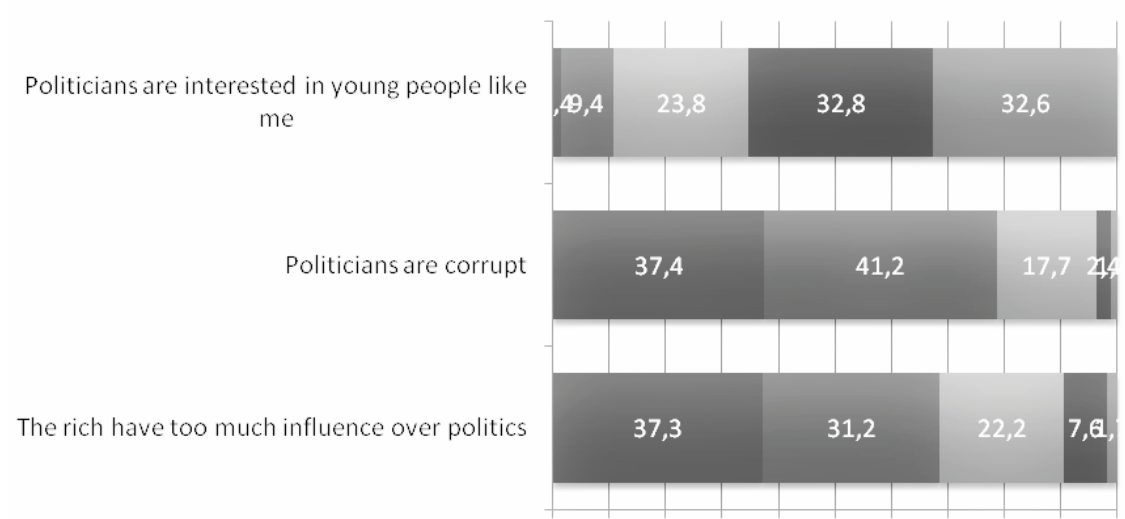

$0 \% \quad 10 \% 20 \% 30 \%$ 40\% 50\% $60 \% 70 \% 80 \% 90 \% 100 \%$

- Strongly agree $\square$ Agree $\square$ Neither agree nor disagree $\square$ Disagree $\square$ Strongly disagree

\section{Rimavská Sobota}

Politicians are interested in young people like me

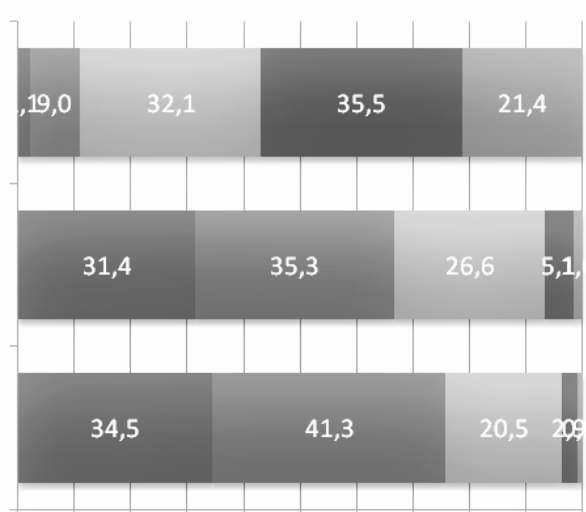

$0 \% \quad 10 \% 20 \% 30 \% 40 \% 50 \% 60 \% 70 \% 80 \% 90 \% 100 \%$

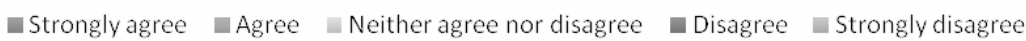

Furthermore, trust in social and political institutions was studied asking the following question: Please, tell us how much you trust in the following institutions and organizations, using a 0 to 10 scale. 0 means "do not trust at all" and 10 - "fully trust”. 


\section{Figure 3: Trust in social and political institutions across field sites ("How much do you trust the following institutions and organizations?")}

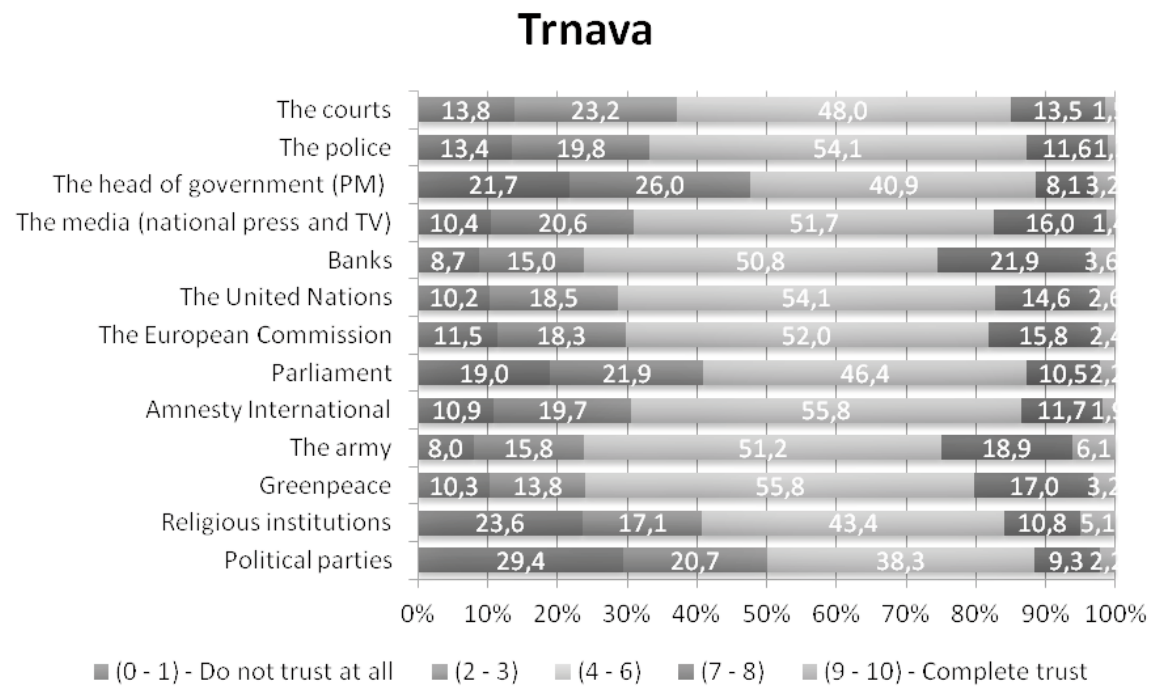

\section{Rimavská Sobota}

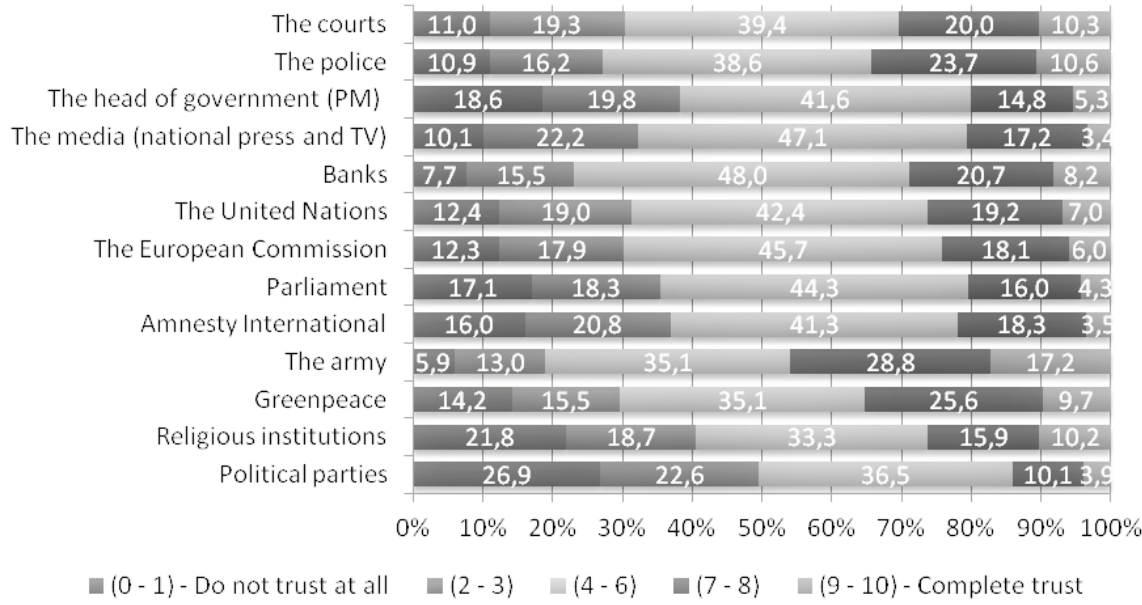

The survey analysis confirmed that among the least trusted social institutions as indicated by the respondents are political parties that correspond to $26.9 \%$ trust in Rimavská Sobota and 29.4\% in Trnava. The following least trusted institutions are those related to religious practice such as church or chaples $(21.8 \%$ in Rimavská Sobota 
and $23.6 \%$ in Trnava). From the comparative perspective of the two field sites, police, Greenpeace and army are highly trusted in Rimavská Sobota, while in Trnava it is more visible that banks are leading institutions in expressed trust toward social organizations.

Other identification markers of the respondents such as gender, age, ethnic affiliation, marital status, education, employment or social status are not expressed as significantly as in the case of trust in social institutions.

The respondents in both locations claim there is a political party they support and have clearly selected their favourite political platforms - this ranks approximately at $38 \%$ of respondents in both locations. Principally, respondents identified those political parties and leaders that received votes from them in the most recent parliamentary and local elections.

The respondents with tertiary education both in Trnava (60\%) and Rimavská Sobota $(57.1 \%)$ have the best shaped idea of a popular political party. In this respect, we refer to the following political parties:

- University students in Rimavská Sobota voted for Most-Híd (23.6\%) and SmerSD $(34.7 \%)$

- University students in Trnava voted for KDH (16.7\%), SaS (21.4\%) and Smer$\mathrm{SD}(23.8 \%)$.

The attitude of young people in both locations to politics and politicians is very critically unambiguous. The most negative statement is that politicians are corrupt, followed by the rich having too much or visible influence on politics, and finally. On the other hand, the statement that politicians are interested in the young generation proved to be invalid.

The analysis of the relation between the level of knowledge about politics and politicians in the country with certain civil opinions and attitudes has shown that it is a case of a differentiated structure. However, the level of political knowledge of the respondents does not express how they assess politicians and current politics in their country. In all above cases the level of political knowledge has no impact on opinions and attitudes of young people. Thus, the results confirm the fact that civil and political opinions and attitudes are not influenced by the level of civic knowledge of the respondents. The overall awareness of young people of politicians, political parties and mechanisms how politics is made is equal among all groups of the respondents from the regional as well as urban-rural environments.

Our respondents were given a chance to express their opinions concerning the way their country is governed. Both parliamentary democracy and an authoritative political system are each presented by two indicators. Basically, the respondents in both locations in Slovakia:

- support parliamentary democracy with a strong position of the non-coalition parties; 
- sharply reject a political system with a "military dictatorship": Trnava $-66.4 \%$, Rimavská Sobota - 59\%;

- less sharply reject government of a strong leader with weak parliament (authoritarian governance): Trnava-44.8\%, Rimavská Sobota-34.2\%.

The authoritative system of government in Slovakia after 1993 is connected with the governments of Vladimír Mečiar (1993 - 1998). Similarly, the formation of government by a single party after 2012 parliamentary elections the opposition labelled the government of Robert Fico in this way because the political party Smer - Social Democracy has 85 deputies out of 150 in parliament. Opinions of our respondents in this research deal with this specific situation in Slovakia (Figure 4).

\section{Figure 4: Positions to political leadership across the two field sites ("How much do you agree/disagree with the following statements?")}

\section{Trnava}

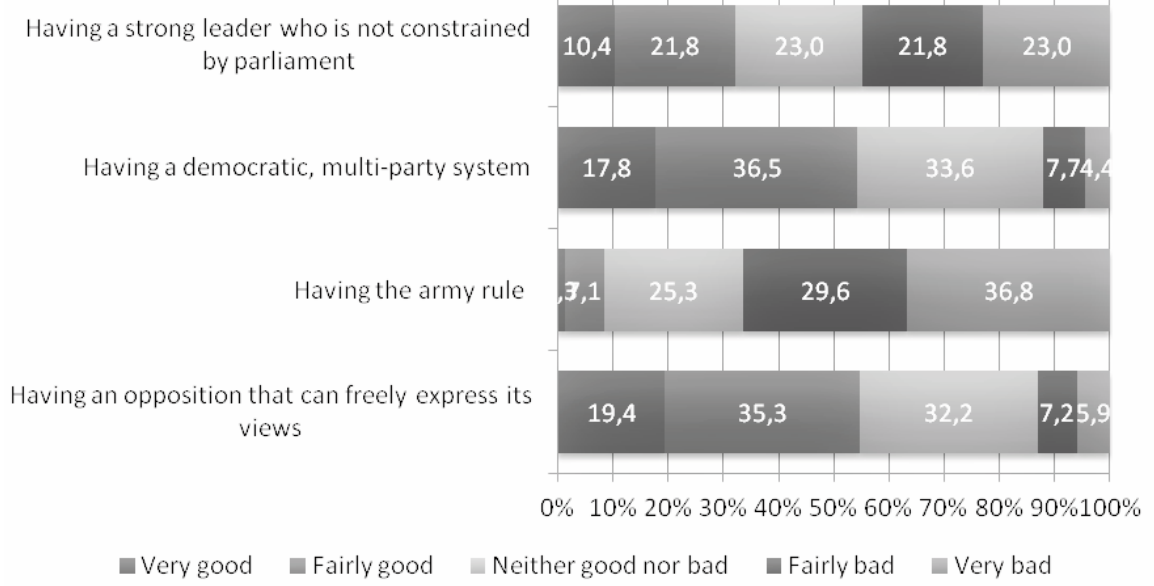




\section{Rimavská Sobota}

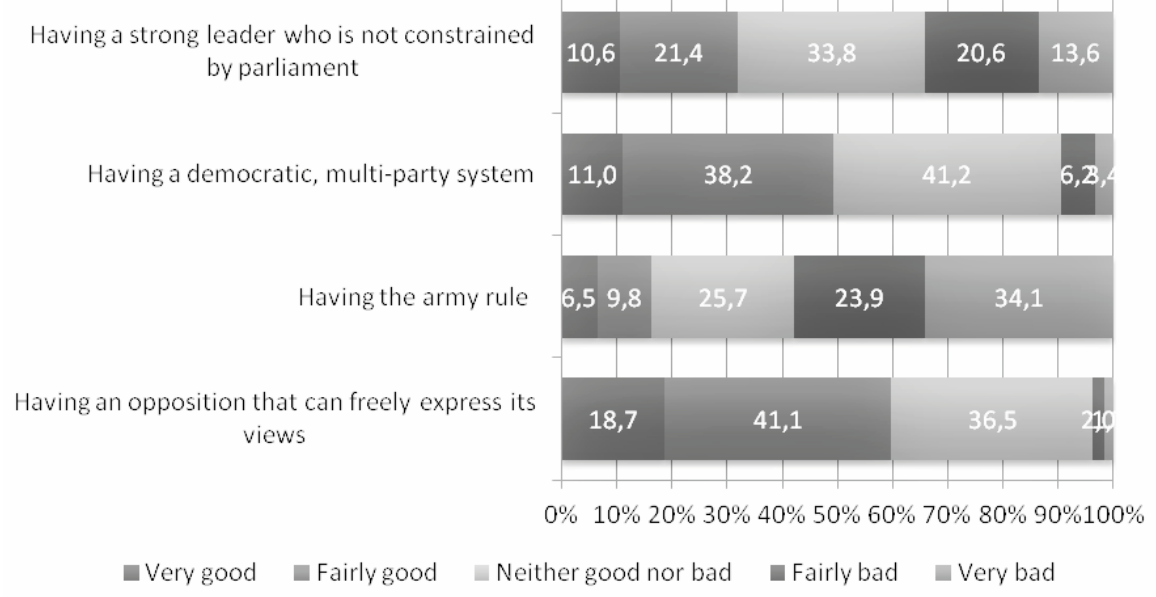

The structural analysis has shown some remarkable differences in the level of statistical significance:

- In Rimavská Sobota, mainly the members of the highest social class reject a "strong leader" (63\% finds it very bad).

- In Trnava, a strong leader is surprisingly more supported by the employed respondents than the unemployed ones.

\section{Conclusion}

Since 1995, the education for democratic citizenship (EDC) has been one of political priorities of the EU as a set of practices and principles aimed at preparing adolescents and adults better for active engagement in democratic life by empowering and defending their rights and responsibilities in the society. Mainly, it was a response to strengthening of the process of integration of European post-communist countries to the new European community by adopting European democratic values and political culture of European governance by its young generation.

Civic knowledge of young people should be embraced in everyday life - outcomes of international projects such as MYPLACE indicated that civic knowledge represents an important cornerstone of processes of preparation of young people's engagement in democratic governance in countries such as Slovakia.

Sociological survey in Slovak locations reveals the urban-rural division of political participation-MYPLACE sociological survey contributed to the Commission's initiative 
by its specific approach testing urban-rural division line of political participation by selecting representative survey samples of young people in two different regions. Division of respondents depending on the level of their political knowledge made it possible to confirm that even elementary political knowledge differentiates young citizens from the viewpoint of their overall interest in politics. Respondents with a higher level of political knowledge perceive themselves and their closest friends as people with a higher level of interest in politics, either at national or even European level.

The support for authoritarianism should not be driven by political knowledge in the urban-rural discourse - regarding the political opinions and attitudes of youth, we identified areas (corruption of politicians, inappropriate influence of the rich on politics, low interest of politicians in the youth) of critical and negative assessment of politics and politicians that did not depend on the level of political knowledge of respondents. There are young citizens who support authoritarianism less and rather oppose it. That is fully in line with sociological analyses that have claimed the urban-rural division line in Slovakia is important. Based on the findings, citizens living in rural areas are more conservative, more nationalistic, and more religious. Verification of the hypothesis that citizens in rural areas incline to authoritarianism more than people living in towns means that a significant group of young rural citizens (Rimavská Sobota), even those with high level of knowledge of politics, do not either support or resist the orientation and they do not find it either good or bad.

Low level knowledge supports the authoritarian procedures - Based on empirical findings of the MYPLACE data we verified the hypothesis that a low level of political knowledge is strongly connected to the highest support toward authoritarian procedures in governance. Even though the group of young people in Trnava with the lowest level of political knowledge is the smallest out of all, it showed the strongest support to "a strong personality of a leader". That is in line with knowledge of mobilization of a part of the youth in the city of Trnava in favor of radical action groups of sport fan clubs.

\section{Bibliography}

BOLDEN, R. (ed), (2004) What is Leadership? Leadership South West Report 1, University of Exeter, Exeter

BRYSK, A. (2002), Globalization and Human Rights, University of California Press, Berkeley

CHOI, S. (2007) Democratic Leadership: The Lessons of Exemplary Models for Democratic Governance, in International Journal of Leadership Studies (2) 3

EUYOUPART (2005) Political Participation of Young People in Europe-Development of Indicators for Comparative Research in the European Union. [online] http://www.sora.at/fileadmin/images/content/Pages/euyoupart_ergebnisse_ 
finalcomparativereport.pdf [accessed 28 April 2015]

FURLONG, A. and CARTMEL, F. (1997) Young People and Social Change: Individualisation and Risk in the Age of High Modernity, Open University Press, Buckingham

GREENSTEIN, F. (2004) The Presidential Difference: Leadership Style from FDR to George W. Bush, Princeton University Press, Princeton NJ

HORVÁTH, P. and MIHÁLIK, J. (2011) SMER-SD and FIDESZ: The National Interests and Populism in the 2010 Parliamentary Elections, in Innovative Issues and Approaches in Social Sciences (4) 2

IGNAZI, P. (2003) Extreme Right Parties in Western Europe, Oxford University Press, Oxford

KING, A. (2002) Leaders' Personalities and the Outcomes of Democratic Elections, Oxford University Press, New York

MACHÁČEK, L. (2008) Občiansky deficit mládeže: Politická a občianska participácia študentov na Slovensku, Slovenská spoločnost’ pre výskum mládeže: IUVENTA Bratislava

MASCIULLI, J. and DAY R. B. (2006) Governing a Global Community of Shared Risks, in Richard B. Day and Joseph Masciulli (eds), Globalization and Political Ethics, Brill, Leiden

MASCIULLI, J., MOLCHANOV M. A., and KNIGHT W. A. (2009) Political Leadership in Context, Ashgate Publishing

NYE, J. Jr (2008) The Powers to Lead, Oxford University Press, New York

WEBER, M. (1986) ‘Types of Authority', in KELLERMAN (ed.) Political Leadership:

A Source Book, University of Pittsburgh Press Pittsburgh

PhDr. Jaroslav Mihálik, PhD. His research covers youth political and civic engagement, nationalism studies and trends of political leadership and democratic performance.

PhDr. Jaroslav Mihálik, PhD.

Faculty of Social Sciences, University of Ss. Cyril and Methodius, Trnava, Bučianska 4/A, 91701 Trnava, Slovakia. email: jaroslav.mihalik@ucm.sk 